\title{
Development of Teachers' Beliefs as a Core Component of their Professional Identity in Initial Teacher Education: A Longitudinal Perspective
}

Vlasta Vizek Vidović ${ }^{1}{ }^{1}$ and Vlatka Domović ${ }^{\star 2}$

$\approx$ The main aim of this research is to longitudinally examine the shift in teaching students' professional beliefs about the teacher-pupil role during the course of their studies. The starting assumption has been that teachers' professional development is largely dependent upon their beliefs about various aspects of their professional role. The beliefs about the teacherpupil role are the building blocks of teachers' professional identity, which strongly influence the way they teach and communicate with pupils. The participants in the research are 62 student teachers, from three teacher education faculties, who were prepared to teach in the lower grades of primary school. The research was carried out in two waves, at the beginning and at the end of the five-year study programme. The beliefs were explored using a metaphor technique derived from the cognitive theory of metaphor. The results indicate that exposure to the study programme did not considerably affect the change in the belief orientations, meaning that pre-professional beliefs remained unchanged, especially in the perception of the pupil's role. That finding has been discussed in relation to the possible implications for the initial teacher education curriculum and its implementation.

Keywords: teachers' beliefs, teacher's role, metaphors, teacher education curricula

1 Faculty of Philosophy, University of Zagreb and Institute for Social Research, Coratia.

$2{ }^{\star}$ Corresponding Author. Faculty of Teacher Education, University of Zagreb, Croatia; vlatka.domovic@ufzg.hr. 


\section{Razvoj pogledov učiteljev kot temeljne komponente njihove poklicne identitete $\mathrm{v}$ začetnem izobraževanju učiteljev: longitudinalna perspektiva}

Vlasta Vizek Vidović in Vlatka Domović

$\propto$ Glavni cilj longitudinalne raziskave je preučevanje spremembe v strokovnih pogledih študentov razrednega pouka glede vloge učitelj - učenec med njihovim študijem. Izhodiščna predpostavka je bila, da je poklicni razvoj učiteljev v veliki meri odvisen od njihovega dojemanja različnih vidikov njihove poklicne vloge. Pogledi na vlogo učitelj - učenec so gradniki poklicne identitete učiteljev, ki močno vplivajo na način poučevanja in komuniciranja $\mathrm{z}$ učenci. $\mathrm{V}$ raziskavi je sodelovalo 62 študentov razrednega pouka s treh pedagoških fakultet, ki so bili usposobljeni za poučevanje $\mathrm{v}$ nižjih razredih osnovne šole. Raziskava je potekala $\mathrm{v}$ dveh delih - na začetku in ob koncu petletnega študijskega programa. Njihove poglede smo preučili s tehniko metafore, ki izhaja iz kognitivne teorije metafore. Izsledki kažejo, da vpetost učiteljev v študijski program ni bistveno spremenila njihovih pogledov; ti so ostali nespremenjeni tudi po nastopu službe, zlasti za to, kar zadeva dojemanje učenčeve vloge. Ta ugotovitev je bila obravnavana $z$ vidika mogočih posledic za pripravo učnega načrta za izobraževanje učiteljev in njegovo izvajanje.

Ključne besede: pogledi učiteljev, učiteljeva vloga, metafore, učni načrti za izobraževanje učiteljev 


\section{Introduction}

Initial teacher education can be regarded as a starting period for the professional development and socialisation of teachers. The traditional perspective of initial teacher education emphasises the importance of the acquisition of specific domain (subject) knowledge and teaching skills but is less oriented toward building teachers' professional identity through development of teacher's professional values, beliefs, and attitudes (Beauchamp \& Thomas, 2009; Feiman-Nemser, 2001; Rogers, 2011; Sutherland \& Markauskaite, 2012).

Zeichner and Gore (1990) describe teachers' socialisation as a threestage process. It starts with educational experiences prior to formal teacher education (anticipatory socialisation), followed by the period of initial teacher education and continuing throughout teaching service in schools. The initial teacher education is a stage of teacher socialisation in which students begin constructing their professional identity.

Professional identity is recognised as a complex and challenging concept, without a generally accepted definition but, at the same time, there is a general agreement on its significance and influence on teachers' professional behaviour (Beauchamp \& Thomas, 2009; Izadinia, 2013; Thomas \& Beauchamp, 2011). Rodgers and Scott (2008) summarised basic assumptions for the analysis of teachers' professional identity as follows:

- identity is dependent upon and formed within multiple contexts that bring social, cultural, political, and historical forces to bear upon that formation,

- identity is formed in relationship with others and involves emotions,

- identity is shifting, unstable, and multiple,

- identity involves the construction and reconstruction of meaning through stories over time.

For Kosnik and Beck (2009), teachers' professional identity means the way teachers perceive themselves professionally including their sense of their goals, responsibilities, style, effectiveness, level of satisfaction, and career trajectory. Some authors have defined professional identity as an image that teachers have of themselves (Singh \& Richards, 2006) and some believe that teachers' professional identity is a conceptualisation of a certain type of person in a specific context (Gee, 2000). Korthagen assumes that 'professional identity often takes on the form of a Gestalt: an unconscious body of needs, images, feelings, values, role models, previous experiences and behavioural tendencies, which together create a sense of identity' (2004, p. 85). Beijaard and Meijer (2017) 
define teachers' identity as one's image of oneself as a teacher, depending upon the interplay of personal and professional factors. In that sense, the authors claim that 'becoming a teacher results from the interaction between student teachers beliefs $[\ldots]$ and educational context in which they find themselves including generally accepted theories of teaching and learning' (2017, p. 177).

Teachers' beliefs have an essential role in their identity formation, which later has a strong impact on their professional behaviour and actions. Beliefs can be understood as mental representations of reality that are often emotionally coloured and experienced as something true without the need for rigorous examination. Teachers' beliefs cover a wide range of concepts that serve as a tool for understanding and steering their professional activities and roles (Pajares, 1992; Zheng, 2009). As they are often rooted in early educational experiences of being a pupil, the affective component is relatively pronounced and can influence teachers' professional conduct irrespective of the knowledge and skills acquired during initial teacher education (Gürsoy, 2013; Raths, 2001).

Teachers' professional beliefs can be classified into four broader categories: educational beliefs, beliefs about teacher role, beliefs about learning and learners and beliefs about self-efficacy. Educational beliefs refer to implicit theories about the purpose of education. Beliefs about teachers' roles refer to teachers' competences and tasks. Beliefs about learning and pupils refer to the understanding of the learning process and the nature of pupils' capabilities and capacities for learning. Beliefs about self-efficacy refer to the perception of personal competence in a concrete professional context. In all belief categories, a distinction between constructivist, student-centred views, and traditional, teacher- and discipline-centred views of teaching and learning emerges as a common theme (e.g., Bandura, 1997; Brophy \& Good, 1986; Domović, Vizek Vidović, \& Bouillet, 2016; Dweck, 2000; Eccles \& Wigfield, 2002; Zheng, 2009,).

The more recent research (Morrison, 2013; Pillen, Beijaard, \& den Brok, 2013) in the field of professional identity formation reveals that its development can be hindered by the conflict between personal and professional beliefs. Morisson (2013) identified three trajectories in the identity formation of beginning teachers: emergent, distressed, and tenuous. The first refers to the beginning teachers who did not experience deep conflicts between their personal and professional beliefs. Those teachers showed confidence in their competences and optimism regarding their future teaching career. Such positive feelings were mainly due to adequate professional support. The distressed trajectory refers to teachers who experienced significant tensions between their professional and personal beliefs. Therefore, they felt insecure and had low self-confidence in what they did. Often, they felt isolated and lacking adequate professional 
support. They were at the high risk of leaving the profession. The tenuous trajectory refers to teachers who oscillated between the emergent and distressed trajectory. In their research on professional tensions, Pillen et al. (2013) pointed out that most beginning teachers will have to cope with the tensions related to their professional identity. In their research, they identified 59 tensions, which were grouped into three broader categories: the changing role from student to teachers, the conflicts between desired and actual support given to students, and the conflicting conceptions of learning to teach. It has been observed that these tensions are often accompanied by feelings of helplessness, frustration, and anger. The tensions also can have positive growth effects on teacher identity development if they are successfully resolved. If a teacher does not possess adequate coping strategies to overcome these tensions, it may lead to professional crises (Alsup, 2006; Pillen, 2013).

The enhancement of teacher capacities for coping with those tensions mainly depends upon the availability of adequate support for understanding and resolving potential conflicts between personal and professional beliefs during the initial teacher and induction. In that respect, the teacher educators and school practice mentors should be able to address students' conflicting beliefs, emphasising the need for reconciliation between personal beliefs and professional expectations. Some of the most useful tools for addressing student beliefs appeared to be combinations of dialogs and narratives embodied in the teaching process, the creation of an atmosphere of openness and mutual trust between students and teachers, and the usage of a variety of dialogs (self-dialog, peer dialog, and supervisory dialog) (Leijen et al., 2014, in Beijaard \& Meijer, 2017). Yet another approach at the individual level is necessary for building the competence for self-reflection. The concept of reflection is often inherent in teacher education study programmes. However, closer inspection of the nature of reflection in practice shows that it is more directed to a solution of practical problems than to the underlying beliefs and self-images that strongly influence teachers' behaviour. Those insights led Korthagen and Vasalos (2005) to the development of the model of structured reflections, which enables a person to realise what happens in the deeper layers of personal and professional self (mission, identity, beliefs), which affect motivation and actions in teaching. In that respect, the authors see such 'core reflection' as a primary tool for the enhancement of professional growth (Korthagen \& Vasalos, 2005; Korthagen \& Verkuyl, 2002).

Samuel and Stephens (2000) state that during initial teacher education the prospective teachers' identity is influenced by three rival spheres of influence: the personal sphere, which encompasses students' previous educational 
and social experience; the institutional sphere, which encompasses the influence of institutional factors, such as curricula, teaching methods, teaching staff and school-based practice; and the contextual sphere, which refers to the factors of the wider educational and social environment.

The development of teachers' professional identity during their initial education should be especially addressed in the teaching and learning process. Intuitive beliefs and stereotypes about teachers' roles, which prospective teachers bring to the initial professional education, should be raised to the level of student awareness, increasing the opportunity for their change in line with the professional approaches to teaching and learning. If this is not done, these intuitive beliefs will continue to act as strong perceptual, cognitive filters affecting the impact of educational context and professional behaviour (Domović, 2011; Domović \& Vizek Vidović, 2013; Feiman-Nemser, 2001). In respect to that, as the key task of initial teacher education, some authors identify the development of the awareness of the complexity of the role of the teacher and the gradual transformation of intuitive beliefs about learning and teaching into professional beliefs based in educational sciences/concepts (Lamote \& Engles, 2010; Lopes \& Pereira, 2012; Tryggvason, 2012).

Feiman-Nemser (2008) describes the complexity of teachers' roles by assuming that there are four fundamental aspects of teachers' learning: learning to think, feel, know, and act as teachers. The first two aspects, 'learning to think as teachers' and 'learning to feel as teachers', relate to the development of pedagogical thinking and the development of intellectual and emotional aspects of professional identity, including beliefs, attitudes and expectations. The other two, 'learning to know as teachers' and 'learning to act as teachers', comprise cognitive requirements and behavioural aspects of teacher practices.

This study aimed to verify whether exposure to a five-year study programme brought about shifts in professional beliefs by comparing students' beliefs about teachers' and learners' roles at the beginning and at the end of their initial teacher education. Institutions of initial teacher education are assumed to have an important role in the construction, as well as in the reconstruction of the future teachers' professional identity. Teachers' perceptions of their professional role and competencies affect their self-efficacy as well as their willingness to cope with professional challenges and ability to implement innovations in their teaching practice (Beijaard, Verloop, \& Vermunt, 2000). The hypothesis is that during initial teacher education the shift should occur from students' pre-professional beliefs of teachers' and pupils' roles developed at earlier educational stages toward the understanding of teaching and learning based on educational sciences (Feiman-Nemser, 2008). 


\section{Research context: Initial teacher education in Croatia}

In Croatia, all categories of school teachers are educated at the university level, but depending on the educational level at which they teach and their profile, they are enrolled in different types of study programmes at different university institutions. These categories are teachers who teach in Grades 1 to 4 of elementary school (class-teachers), subject teachers in Grades 5 to 8 of elementary school, subject teachers in secondary academic schools (gimnazija), teachers of general education subjects in secondary vocational schools, and teachers of vocational subjects in secondary vocational schools. In this paper, the focus is exclusively on student teachers preparing for class teaching (Grades 1 to 4 of elementary school).

Major changes in the initial education of class-teachers occurred with the implementation of the Bologna process in higher education. Since the 2005/6 academic year, class-teachers are educated at teacher education faculties through five-year integrated study programmes leading to a master's degree in education (300 ECTS credits). The underlying rationale for adopting the integrated model instead of a two-cycle model supported by the Bologna principles has been the complexity of the teacher's role in the first four grades of schooling, in which one teacher teaches all subjects to the same cohort of pupils over four years. After graduation, class-teachers are qualified to teach six subjects in the lower grades of elementary schools: native language, science and society, mathematics, visual arts, music arts, and physical education (Domović \& Vizek Vidović, 2011). To develop their teaching competences, the study programme for prospective classteachers includes courses devoted to subject knowledge, educational sciences, teaching methodology courses, and school-based practice. Although there are some variations of curricula across teacher education faculties, approximately $40 \%$ of study time is devoted to subject knowledge, $15 \%$ to educational sciences, $35 \%$ to teaching methodology courses and $10 \%$ to school-based practice. In general, the focus of the first three years of study is on the subject knowledge and educational sciences, while the last two years are mainly devoted to subject teaching methodologies and school practice (Domović, Vizek Vidović, \& Bouillet, 2016). The inspection of the study programme documents reveals that they are conceptually rooted in the constructivist approach to teaching and learning. It is supposed that the teacher educators would adhere to implementing the constructivist perspective across curriculum courses. Therefore, it might be expected that if such a perspective is consistently applied at all levels of the study programme, the graduate students will demonstrate professional beliefs that emphasise the constructivist conception of the teacher as a facilitator of pupils' meaningful learning. 


\section{Research questions}

The research questions were formulated as follows:

- What are the students' intuitive beliefs about teachers' and pupils' roles upon the entrance to professional education?

- Is there any shift in students' beliefs about teachers' and pupils' role from the beginning and to the end of their initial teacher education?

\section{Method}

\section{Participants}

Participants were students from three Croatian teacher education faculties who were preparing to be classroom teachers of Grades 1 to 4 in elementary school. They were invited to participate in the research twice: in study year $2011 / 2012$ in the first year of their studies $(\mathrm{N}=150)$ and again in 2015/2016 in the fifth year, at the end of their study programme $(\mathrm{N}=62)$. All participants were female.

\section{Research Design}

The research was based on a prospective longitudinal design (Cohen, Manion, \& Morrison, 2005; Menard, 1991). In this case, the longitudinal study was carried out over an extended period. Data were collected in two waves with the five-year interval. The cohort consisted of individuals from three teacher education faculties who were invited to participate twice: at the beginning and at the end of their study programme. The first data collection occurred at the beginning of the first semester with 150 participating students. In the last semester of the study programme, all students enrolled in the fifth year were invited to participate in the second wave, but only 100 of them responded. Among those 100, only 62 individuals were eligible for the analyses as they participated on both occasions.

As the study was conducted anonymously, the same individuals were identified by using the same code each time. The code, which consisted of their mother's initials and birth date, was such that they could easily remember it after a five-year period. In that way, their responses could be easily paired for comparison. At both times of data collection, the same answer sheets were administrated by researchers during regular classes. The completion of the answer sheets took about 20 minutes. As mentioned above, after comparing students' codes, 62 students who participated in the first and the second part of the study could be identified, and their responses were analysed. 


\section{Instrument}

Although the importance of teaching students' beliefs about teachers' and pupils' roles is often emphasised, both quantitative and qualitative measures are relatively scarce (e.g., Woolley, Woan-Jue, \& Williams Woolley, 2004). The present study is a part of a larger research project on teacher professional development. For the purpose of the project, a comprehensive inventory was constructed using both quantitative and qualitative measures of teaching students' characteristics. Quantitative measures were used for the investigation of several motivational and personality variables (e.g., self-efficacy, motivation to teach, personality characteristics linked to the Big-5 model) related to teaching students' early professional socialisation, while student teachers' beliefs were assessed only qualitatively using a metaphor technique.

Regarding the development of teachers' professional identity, the metaphor technique is used as an analytical tool for the exploration of complex experiences and underlying beliefs. The logic of metaphor use is to start with familiar objects or events as a stimulus for the interpretation of concepts or situations, leading to new conceptual insights (Massengill, Barry, \& Mahlios, 2008; Saban, 2010; Zhao, Coombs, \& Zhou, 2010).

The students were asked to complete two unfinished sentences by focusing on a single metaphorical image. The prompts were formulated as follows:

'A teacher is like. because

'A pupil is like... because

\section{Data analysis}

The data analysis was based on a qualitative approach known as inductive thematic analysis (Braun \& Clarke, 2006) derived from the cognitive theory of metaphor (Saban, Kocbeker, \& Saban, 2007). Thematic analysis is a method for identifying, analysing, and reporting patterns within qualitative data. In the process of data analysis, the key phases and actions described by Braun and Clarke (2006) were followed:

- $\quad$ familiarising oneself with data - reading and rereading the data, noting down initial ideas

- $\quad$ generating initial metaphor codes - sorting features of the data systematically across the entire data set

- searching for themes - collating metaphor codes into potential categories and naming of categories

- reviewing categories - checking the fit of coded extracts to the categories

- merging themes into theoretically derived categories

- $\quad$ quantitative data analysis. 
The first two steps of data analysis were done independently by three researchers. In the next step, themes or patterns were established based on common agreement between all researchers. After establishing the key patterns, the authors worked together on data processing and the interpretation of results.

\section{Results}

According to the aim of the study, the first step in data analysis was the identification of the main themes derived from the inspection of original metaphors about teachers' and pupils' roles. Following the abovementioned procedure, the researchers agreed upon seven themes of teachers' roles (Table 1) and four themes of pupils' roles (Table 2). In both cases, there were a few responses that could not be classified.

Table 1

Themes with examples of teachers' metaphors - the first and fifth study years

\begin{tabular}{|c|c|}
\hline Theme & $\begin{array}{l}\text { Metaphor: } \\
\text { 'A teacher is like ........... because ............' }\end{array}$ \\
\hline \multirow{2}{*}{ Parent } & $\begin{array}{l}{ }^{7 s t} \text { year - A teacher is like a parent, because he/she cares about pupils, teaches } \\
\text { them, nurtures, and prepares them for the future. }\end{array}$ \\
\hline & $\begin{array}{l}5^{\text {th }} \text { year - A teacher is like another parent, because he/she takes care of chil- } \\
\text { dren when they are at school. }\end{array}$ \\
\hline \multirow{2}{*}{$\begin{array}{l}\text { Source of knowl- } \\
\text { edge/wisdom }\end{array}$} & ${ }^{\text {st }}$ year - A teacher is like a book, because he/she knows a lot. \\
\hline & $\begin{array}{l}5^{\text {th }} \text { year - A teacher is like GOOGLE, because he/she must have answers to all } \\
\text { pupils' questions. }\end{array}$ \\
\hline \multirow{2}{*}{ Guide } & 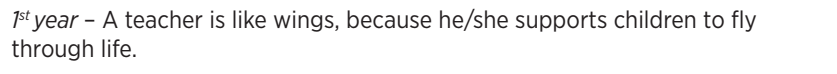 \\
\hline & $\begin{array}{l}5^{\text {th }} \text { year - A teacher is like the moon, because he/she shows the path in the } \\
\text { dark. }\end{array}$ \\
\hline \multirow{2}{*}{ Shaper } & ${ }^{\text {st }}$ year - A teacher is like an artist, because he/she shapes the pupil. \\
\hline & $5^{\text {th }}$ year - A teacher is like a model, because pupils try to imitate him/her. \\
\hline \multirow{2}{*}{ Friend } & $\begin{array}{l}7^{s t} \text { year - A teacher is like a friend, because he/she is always helpful, comforting } \\
\text { and reliable. }\end{array}$ \\
\hline & $\begin{array}{l}5^{\text {th }} \text { year - A teacher is like a friend, because he/she is emphatic, helpful and } \\
\text { listens to children. }\end{array}$ \\
\hline \multirow[b]{2}{*}{ Authority/power } & $7^{\text {st }}$ year - A teacher is like a ruler, because he/she decides what will be learned. \\
\hline & $\begin{array}{l}5^{\text {th }} \text { year - A teacher is like a manager, because he/she imposes knowledge and } \\
\text { skills upon pupils. }\end{array}$ \\
\hline \multirow{2}{*}{ Self-pity } & $\begin{array}{l}7^{\text {st }} \text { year - A teacher is like an artist who is worried about producing a worthless } \\
\text { piece of art. }\end{array}$ \\
\hline & $\begin{array}{l}5^{\text {th }} \text { year - A teacher is like a squeezed orange, because everybody is taking } \\
\text { something away from him/her. }\end{array}$ \\
\hline
\end{tabular}


${ }^{7 s t}$ year - A teacher is a person who teaches pupils because he/she has adequate education

Unspecified

$5^{\text {th }}$ year - A teacher is a very important person for children, because he/she gives them the most important knowledge.

Table 2

Themes with examples of pupils' metaphors - the first and fifth study years

\begin{tabular}{|c|c|}
\hline Theme & $\begin{array}{l}\text { Metaphor: } \\
\text { 'A pupil is like ........... because ............' }\end{array}$ \\
\hline \multirow{2}{*}{ Object } & $\begin{array}{l}7^{\text {st }} \text { year - A pupil is like a sponge, because he/she soaks up all knowledge and } \\
\text { information. }\end{array}$ \\
\hline & $\begin{array}{l}5^{\text {th }} \text { year - A pupil is like plasticine, because in good hands he/she can be trans- } \\
\text { formed into a work of art. }\end{array}$ \\
\hline \multirow{2}{*}{ Plant } & $\begin{array}{l}1^{\text {st }} \text { year - A pupil is like a flower, because he/she grows slowly, is delicate, lovely } \\
\text { and needs a lot of warmth. }\end{array}$ \\
\hline & $\begin{array}{l}5^{\text {th }} \text { year - A pupil is like a bud, because he/she needs care and water to become a } \\
\text { beautiful flower. }\end{array}$ \\
\hline \multirow[b]{2}{*}{ Child } & ${ }^{\text {jt }}$ year - A pupil is like a child, because the teacher is his/her other parent. \\
\hline & $\begin{array}{l}5^{\text {th }} \text { year - A pupil is like a small lamb, because he/she is lost in the world and } \\
\text { needs help and protection. }\end{array}$ \\
\hline \multirow{2}{*}{ Explorer } & $\begin{array}{l}{ }^{\text {st }} \text { year - A pupil is like a curious and restless creature, because he/she is occupied } \\
\text { all the time and shows interest in many things. }\end{array}$ \\
\hline & $\begin{array}{l}5^{\text {th }} \text { year - A pupil is like a small bee, because he/she is diligent, inquisitive and } \\
\text { always ready for new activities and knowledge. }\end{array}$ \\
\hline \multirow{2}{*}{ Unspecified } & $\begin{array}{l}7^{\text {st }} \text { year - A pupil is a person who has the task of attending lessons, because it will } \\
\text { help him/her to do homework. }\end{array}$ \\
\hline & $\begin{array}{l}5^{\text {th }} \text { year - A pupil is a person attached to the teacher, because he/she spends a lot } \\
\text { of time with him/her and sees a lot good in a teacher. }\end{array}$ \\
\hline
\end{tabular}

According to Brown and Clarke's (2006) approach to qualitative data analysis, the distinctive step following the steps 'search for themes' and 'review of categories' is 'merging themes into theoretically derived categories'. In this phase, the initial themes were further grouped into broader categories or orientations based on major theoretical concepts about teaching and learning (e.g., Martínez, Sauleda, \& Huber, 2001). Four broader categories or orientations for teacher metaphors were recognised: behaviourist orientation, facilitating orientation, protective orientation, and self-referencing orientation.

The behaviourist orientation is based on the conventional stimulus-reaction paradigm. In that perspective, the teacher is seen as an active agent (stimulus) who transmits knowledge to a passive learner, who takes in the content and stores it directly in long-term memory without additional processing (reaction). This orientation covers the following themes for teachers: 'knowledge/ wisdom', 'authority/power', and 'shaper'. 
According to the facilitating orientation, a learner is an active agent in the construction of concepts and meanings, while a teacher acts primarily as a facilitator of learning. This orientation refers to the cognitive constructivist approach to teaching and learning, and it covers only one theme: 'guide'.

The protective orientation is more related to the favourable conditions of learning than to the learning process itself. In this role, the ethics of care are emphasised, and a teacher is primarily responsible for creating an emotionally warm and safe learning environment. This orientation stems from the preprofessional concept of the teacher as an extended family member, and it covers the themes of 'parent' and 'friend'.

Recently, the fourth orientation has emerged as a distinct category in teacher metaphors which was previously usually labelled as a 'miscellaneous' one. Some authors recognised that the common denominator for those metaphors was the self-referencing perspective (Leavy, McSorley, \& Bote, 2007) mainly reflecting students' insecurity and doubts about their capacities for fulfilling their future teaching roles. The rest of the unspecified responses were arranged into the category 'other'.

Those four orientations were used as the basis for the comparison of teaching students' beliefs about the teachers' and pupils' role in the first and fifth (final) years of study. In Tables 3 and 4, changes in orientations could be observed. The ways that each orientation changed from the first to the final year of study could be detected by observing the rows in the tables. In contrast, the shifts in the prominence of each orientation in the fifth year can be seen in the columns.

\section{Teaching students' metaphors for the teacher's role}

In the students' metaphors for the teacher's role, all four orientations were identified as described above. The results of the comparison of the $1^{\text {st }}$ year and $5^{\text {th }}$ year students' responses are shown in Table 3. 
Table 3

Teacher metaphors: The comparison of teaching students' orientations in the first and the final years of study

\begin{tabular}{|c|c|c|c|c|c|}
\hline \multirow{2}{*}{$\begin{array}{l}\text { Orientation }-1^{\text {st }} \text { year } \\
\text { PROTECTIVE (N) }\end{array}$} & \multicolumn{5}{|c|}{ Orientations $-5^{\text {th }}$ year } \\
\hline & $\begin{array}{l}\text { Protective } \\
\text { (N) }\end{array}$ & $\begin{array}{l}\text { Behaviourist } \\
\text { (N) }\end{array}$ & $\begin{array}{l}\text { Facilitating } \\
\qquad(\mathrm{N})\end{array}$ & $\begin{array}{l}\text { Self-referencing } \\
\text { (N) }\end{array}$ & $\begin{array}{l}\text { Other } \\
(\mathrm{N})\end{array}$ \\
\hline 37 & 16 & 4 & 8 & 4 & 5 \\
\hline \multicolumn{6}{|l|}{ BEHAVIOURIST (N) } \\
\hline 12 & 4 & 1 & - & 3 & 2 \\
\hline \multicolumn{6}{|l|}{ FACILITATING (N) } \\
\hline 3 & 1 & 0 & 2 & - & - \\
\hline \multicolumn{6}{|l|}{ SELF-REFERENCING (N) } \\
\hline 3 & 0 & 2 & 2 & 1 & - \\
\hline \multicolumn{6}{|l|}{ OTHER (N) } \\
\hline 7 & 1 & 2 & - & 1 & 3 \\
\hline Total $(\mathrm{N}=62)$ & 22 & 9 & 12 & 9 & 10 \\
\hline
\end{tabular}

Table 3 shows that the most prominent orientation (more than half of the responses, 37 out of 62 cases) referring to the teacher's role in the first year is the protective one. Metaphors with a behaviourist orientation appear in almost one fifth of the responses (12 out of 62 cases). Self-referencing and facilitating are the least present, with only three answers in total. In the final year of study, the most prominent orientation remains the protective one, but less frequently than in the first year. The number of responses for the behaviourist orientation is slightly decreased (12 vs 9). The highest increase could be observed for the facilitating orientation (3 vs 12) and for the self-referencing orientation (3 vs 9). It should be noted that in the responses of both the first-year and the fifth-year students, the category 'other' appears (7 vs 10), which contains responses that were mainly simple textbook definitions of the teacher's role.

\section{Teaching students' metaphors for pupils}

The inspection of teaching students' metaphors for pupils produced three major orientations (behaviourist, facilitating, and protective), while a selfreferencing orientation did not emerge. In the case of pupil metaphors, the behaviourist orientation covers various objects, such as: 'sponge', 'blank slate', 'empty box/glass', and 'white paper'. The facilitating orientation reflects the cognitive-constructive approach, in which the teacher acts as a facilitator of pupils' learning and as a creator of a stimulating learning environment (Domović, 
Vizek Vidović, \& Bouillet, 2016) while the pupil is perceived as a growing entity or explorer. The pupils' themes within this orientation are: 'growing plant' and 'explorer'. The protective orientation is related to the ethics of care covering the theme 'child' for the pupil metaphor.

Table 4

Pupil metaphors: The comparison of teaching students' orientations in the first and in the final years of study

\begin{tabular}{ccccc}
\hline Orientation - 1st year & \multicolumn{5}{c}{ Orientations - 5th year } \\
\hline BEHAVIOURIST $(\mathrm{N})$ & $\begin{array}{c}\text { Behaviourist } \\
(\mathrm{N})\end{array}$ & $\begin{array}{c}\text { Facilitating } \\
(\mathrm{N})\end{array}$ & $\begin{array}{c}\text { Protective } \\
(\mathrm{N})\end{array}$ & $\begin{array}{c}\text { Other } \\
(\mathrm{N})\end{array}$ \\
\hline FACILITATING (N) & 18 & 2 & 5 & 4 \\
10 & 3 & 2 & 0 & 5 \\
\hline PROTECTIVE (N) & 1 & 0 & 3 & 3 \\
7 & & & 1 & 3 \\
\hline OTHER (N) & 10 & 2 & 9 & 15 \\
\hline Total $(\mathrm{N}=62)$ & 32 & 6 & & \\
\hline
\end{tabular}

Table 4 shows that the most prominent orientation (almost half of the responses, 29 out of 62 cases) in the first year is the behaviourist one. The next orientation is other as unspecified (16 out of 62) followed by the facilitating orientation (10 out of 62). The least frequent responses are in the protective orientation (7 out of 62). In the final year of study, the most prominent orientation remains the behaviourist one, showing a slight increase (29 vs 32).

It should be noted that in the category other the number of such unspecified responses is quite high for both the first-year students $(\mathrm{N}=16)$ as well as for the fifth-year students $(\mathrm{N}=15)$. A significant decline can be observed in the fifth-year students $(\mathrm{N}=3)$.

\section{Discussion and conclusion}

Recent authors in the field of teachers' professional development presume that initial teacher education should not only be focused on content knowledge and pedagogical skills but should simultaneously put efforts into supporting the development of prospective teachers' professional identity.

The metaphor technique can be a useful tool for reaching the deeper 
layers of students' selves or - as Korthagen (2004) labelled it - their core identities. Beijaard and Meijer (2017), who perceive beliefs as the building blocks of a teacher's professional identity, point out that it is important to identify discrepancies between students' lay beliefs and research-based teaching and learning concepts. Such tensions, if not properly addressed and successfully resolved during their studies, might provoke deep personal crises combined with professional insecurity and low self-confidence.

The main goal of the present study was to examine whether the educational experience during the initial teacher education influences teaching students' pre-professional beliefs about teachers' and pupils' roles and brings about a shift toward constructivist understandings of teaching and learning as a dominant professional perspective in current teacher education. As the professional identity formation involves the construction and reconstruction of meaning (beliefs) of educational and life-experiences over time (Rogers \& Scott, 2008), the longitudinal research design was used in order to identify changes in beliefs about teachers' and pupils' roles over a five-year study period.

In the study, teaching students' implicit beliefs about teachers' and pupils' roles, expressed using metaphors, were analysed using conceptual tools based on theoretical frames of reference derived from the work of Martinez, Sauleda, and Huber (2001). The four main frames of reference for teacher metaphors were identified: behaviourist, facilitating, protective, and self-referencing orientation. In contrast, only three orientations were identified in the analysis of pupil metaphors: behaviourist, facilitating, and protective orientation.

It is evident that related to pupil metaphors the relatively high proportion of responses was classified as 'other' indicating that teaching students have difficulties in producing metaphoric images of pupils, offering instead concrete definitions of pupils' tasks. It might be assumed that their more distinctive elaboration of teacher metaphors than pupil ones is affected by still-present teacher-educators/teacher-centred approaches to teaching and learning during studies without pupils in clear focus.

Examination of the metaphors for the teachers' roles reveals the somewhat different distribution of responses at two points of the study. Although, on both occasions, the protective orientation is the most dominant one, in the final year of study it somewhat decreases in favour of the facilitating orientation, while the behaviourist orientation remains relatively stable. It should be noted that contrary to some other findings (e.g., Richardson, 1996) in which students predominantly expressed the behaviourist orientation at the beginning of their studies, the prevalence of the protective orientation in this study indicates the pre-professional, naive understanding of the teacher's role as a 
substitute parent. As the behaviourist and protective orientations are the most prominent at the beginning of the studies, these results correspond to the views of other researchers (Leavy, McSorley, \& Bote, 2007) who state that beginning student teachers do not spontaneously develop constructivist beliefs about teaching. It is encouraging that the facilitating orientation increased at the final year of study, although not to the degree that should be expected on the basis of the declared curriculum outcomes. The observed increase in the self-referencing orientation at the end of studies might indicate that some students with unresolved professional tensions become more uncertain and anxious about their future profession. That result certainly deserves closer investigation to obtain insight into how the academic experience affects those students and their perception of the teacher's role.

The comparison of metaphors for the pupil and teacher role reveals that there is little correspondence between them. While student teachers perceive teachers as dominantly protective, their perception of pupils is dominantly behaviourist at both points of investigation. As such, the perception of the pupils' role does not change considerably over time, it might be expected that the future teachers will mostly adhere to the traditional approach to teaching (behaviourist orientation), in which the teacher is an active transmitter of content, and the pupil is a passive recipient.

The slight shifts in the perception of the teachers' role could be observed, but not always in the desirable, constructivist direction. The more upsetting result is the static perception of the pupils' role. It seems that throughout their studies, teaching students remained rooted in their pre-professional beliefs, which were not affected by their academic experience. The inspection of the study programme document reveals that the main goal is the development of teaching competences defined as knowledge and skills. The teachers' professional beliefs and attitudes are not explicitly emphasised and are part of the hidden curriculum agenda. In the documents, the main perspective on teaching and learning is the constructivist approach as a basis for student-centred teaching. It is expected that the teacher educators would implement the constructivist perspective across curriculum courses. Therefore, it might be assumed that if such a perspective is consistently applied at all levels of the study programme, the graduated students would be able to acquire and demonstrate professional beliefs that emphasise the constructivist concept of teaching and learning.

To obtain deeper insight into the student teachers' professional identity development, further exploration in this area should include both students' and teachers' narratives about their academic experience, especially in regard to the tensions between the professional and personal issues as well as classroom 
observations of teacher educators in action.

In conclusion, the results of this study might have some implications for teacher education curricula and especially for their implementation. Initial teacher educators should leave more space for reflective approaches toward academic experiences of student teachers in order to address directly intuitive beliefs about teaching and learning and transform them into intended professional attitudes and values (Domović, Vizek Vidović, \& Bouillet, 2016). The teacher educators should be especially aware of the potential risk of the appearance of personal tensions in students when their pre-professional beliefs are being challenged. It also means that teacher educators themselves should be able to reflect on their own tacit beliefs about their teaching practices and to understand how that might affect their students.

\section{References}

Alsup, J. (2006). Teacher identity discourses: Negotiating personal and professional spaces. New Jersey, NJ: Lawrence Erlbaum Associates.

Beauchamp, C., \& Thomas, L. (2009). Understanding teacher identity: An overview of issues in the literature and implications for teacher education. Cambridge Journal of Education 39(2), 175-189. Bandura, A. (1997). Self-efficacy: The exercise of control. New York, NY: Freeman. Beijaard, D., \& Meijer, P. C. (2017). Developing the personal and professional in making a teacher identity. In D. J. Clandinin \& J. Husu (Eds.), The SAGE handbook of research on teacher education (pp. 177-192). London, UK: SAGE.

Beijaard, D., Verloop, N., \& Vermunt, J. D. (2000). Teachers' perceptions of professional identity: An exploratory study from a personal knowledge perspective. Teaching and Teacher Education, 16(7), 749-764.

Beijaard, D., Meijer, P. C., \& Verloop, N. (2004). Reconsidering research on teachers' professional identity. Teaching and Teacher Education, 20, 107-128.

Brophy, J. E., \& Good, T. L. (1986). Teacher behaviour and student achievement. In M. C. Wittrock (Ed.), Third handbook of research on teaching (pp. 328-375). New York, NY: Macmillan.

Braun, V., \& Clarke, V. (2006). Using thematic analysis in psychology. Qualitative Research in Psychology, 3(2), 77-101.

Cohen, L., Manion, L., \& Morrison, K. (2005). Research methods in education. London, UK: Routledge Falmer.

Domović, V. (2011). Učiteljska profesija i profesionalni identitet učitelja [Teaching profession and teacher professional identity]. In V. Vizek Vidović (Ed.), Učitelji i njihovi mentori (pp. 12-37). Zagreb: Institut za društvena istraživanja.

Domović, V., \& Vizek Vidović, V. (2011). Teacher education in Croatia: Recent developments in teacher education (2005-2010). In M. Valenčič-Zuljan \& J. Vogrinc (Eds.), European dimensions 
of teacher education-similarities and differences (pp. 253-270). Ljubljana: Faculty of Education, University of Ljubljana.

Domović, V., \& Vizek Vidović, V. (2013). Understanding the role of teachers, pupils and teaching Beliefs of students at the Faculty of Teacher Education. Sociologija i prostor, 51(3), 493-508.

Domović, V., Vizek Vidović, V., \& Bouillet, D. (2016). Student teachers' beliefs about the teacher's role in inclusive education. European Journal of Special Needs Education, 32(2), 175-19o. doi:10.1080/0885 6257.2016.1194571

Dweck, C. (200o). Self-theories: Their role in motivation, personality, and development. Philadelphia, PA: Taylor and Francis/Psychology Press.

Eccles, J. S., \& Wigfield, A. (2002). Motivational beliefs, values, and goals. Annu. Rev. Psychol, 53, 109-32.

Feiman-Nemser, S. (2001). From preparation to practice: Designing continuum to strengthen and sustain teaching. Teachers College Record. 103(6), 1013-1055.

Feiman-Nemser, S. (2008). Teacher learning. How do teachers learn to teach? In M. Cochran-Smith, S. Feiman-Nemser, \& D. J. McIntyre. (Eds.), Handbook of research on teacher education. Enduring questions in changing contexts (pp. 697-705). New York, NY \& Abingdon, UK: Routledge/Taylor \& Francis.

Gee, J. P. (2000). Identity as an analytic lens for research in education. Review of Research in Education, 25(1), 99-125.

Gürsoy, E. (2013). What is effective in forming our beliefs: Experience or education? Procedia - Social and Behavioral Sciences, $70(2013), 763-770$.

Izadinia, M. (2013). A review of research on student teachers' professional identity. British Educational Research Journal, 39(4), 694-713.

Korthagen, F. A. J., \& Verkuyl, H. (2002). Do you meet your students or yourself? Reflection on professional identity as an essential component of teacher education. Retrieved from http:// resources.educ.queensu.ca/ar/sstep/S-STEP4-2002b.pdf

Korthagen, F. A. J. (2004). In search of the essence of a good teacher: Towards a more holistic approach in teacher education. Teaching and Teacher Education, 20(1), 77-97.

Korthagen, F. A. J., \& Vasalos, A. (2005). Levels in Reflection: Core reflection as a means to enhance professional growth. Teachers and teaching: Theory and practice, 11(1), 47-71.

Kosnik, C., \& Beck, C. (2009). Priorities in teacher education. London, UK \& New York, NY:

Routledge.

Lamote, C., \& Engels, N. (2010). The development of student teachers' professional identity. European Journal of Teacher Education, 33(1), 3-18.

Leavy, A. M., McSorley, F. A., \& Boté, L. A. (2007). An examination of what metaphor construction reveals about the evolution of preservice teachers' beliefs about teaching and learning. Teaching and Teacher Education 23(7), 1217-1233.

Lopes, A., \& Pereira, F. (2012). Everyday life and everyday learning: The ways in which pre-service teacher education curriculum can encourage personal dimensions of teacher identity. European 
Journal of Teacher Education, 35(1), 17-38.

Martínez, M. A., Sauleda, N., \& Huber, G. L. (2001). Metaphors as blueprints of thinking about teaching and learning. Teaching and Teacher Education, 17(8), 965-977.

Massengill, D., Barry, A., \& Mahilos, M. (2008). Preservice teacher's metaphors of teaching in relation to literacy beliefs. Teachers and Teaching: Theory and Practice, 14(1), 35-50.

Menard, S. (1991). Longitudinal research. London, UK: Sage Publications.

Morrison, C. M. (2013). Teacher identity in the early career phase: Trajectories that explain and influence development. Australian Journal of Teacher Education, 38(4). doi:10.14221/ajte.2013v38n4.5 Pajares, M. F. (1992). Teachers' beliefs and educational research: Cleaning up a messy construct. Review of Educational Research, 62(3), 307-332.

Pillen, M. T. (2013). Professional identity tensions of beginning teachers (Doctoral dissertation).

Eindhoven: Eindhoven University of Technology/ESoE.

Pillen, M., Beijaard, D., \& den Brok, P. (2013). Tensions in beginning teachers' professional identity development, accompanying feelings and coping strategies. European Journal of Teacher Education, 36(3), 240-26o. doi:10.1080/02619768.2012.6961929

Raths, J. (2001). Teachers' beliefs and teaching beliefs. Early Childhood Research \& Practice, 3(1). Retrieved from http://ecrp.uiuc.edu/v3n1/raths.html

Richardson, V. (1996). The role of attitude and beliefs in learning to teach. In J. Sikula. (Ed.),

Handbook of research on teacher education (pp. 102-119). New York, NY: Macmillan.

Rogers, G. (2011). Learning-to-learn and learning-to-teach: The impact of disciplinary subject study on student-teachers' professional identity. Journal of Curriculum Studies, 43(2), 249-268.

Rodgers, C. R., \& Scott, K. H. (2008). The development of the personal self and professional identity in learning to teach. In M. Cochran-Smith, S. Feiman-Nemser, \& J. D. Mclntyre (Eds.), Handbook of research on teacher education (pp. 732-755). New York, NY: Routledge/Taylor \& Francis Group and the Association of Teacher Educators.

Saban, A. (2010). Prospective teachers' metaphorical conceptualizations of learner. Teaching and Teacher Education, 26(2), 290-305.

Saban, A.; Kocbeker, B. N, \& Saban, A. (2007). Prospective teachers' conceptions of teaching and learning revealed through metaphor analysis. Learning and Instruction, 17, 123-139.

Samuel, M., \& Stephens, D. (2000). Critical dialogues with self: Developing teacher identities and roles: A case study of South African student teachers. International Journal of Educational Research, 33(5), 475-491.

Singh, G., \& Richards, J. C. (2006). Teaching and learning in the language teacher course room: a critical socio-cultural perspective. RELC Journal, 37(2), 149-75.

Sutherland, L., \& Markauskaite, L. (2012). Examining the role of authenticity in supporting the development of professional identity: an example from teacher education. Higher Education, 64(6), 747-766.

Thomas, L., \& Beauchamp, C. (2011). Understanding new teachers' professional identities through metaphor. Teaching and Teacher Education, 27(4), 762-769. 
Tryggvason, M. (2012). Perceptions of identity among Finnish university-based subject teacher educators. European Journal of Teacher Education, 35(3), 289-303.

Woolley, S. L., Woan -Jue, J. B., \& Williams Woolley, A. (2004). Construct validity of a self-report measure of teacher beliefs related to constructivistic and traditional approaches to teaching and learning. Educational and Psychological Measurement, 64, 319-331.

Zhao, H., Coombs, S., \& Zhou, X. (2010). Developing professional knowledge about teachers through metaphor research: facilitating a process of change. Teacher Development, 14, 381-395.

Zeichner, K., \& Gore, J. (1990). Teacher socialisation. In W. R. Houston (Ed.), Handbook of Research on Teacher Education (pp. 329-348). New York, NY: MacMillan.

Zheng, H. (2009). A review of research on EFL Pre-service teachers' beliefs and practices. Journal of Cambridge Studies, 4(1), 73-81.

\section{Biographical note}

Vlasta Vizek Vidović, $\mathrm{PhD}$, was a tenured professor of educational psychology of the University of Zagreb. After more than three decades of university career at the Department of psychology, Faculty of philosophy, University of Zagreb, in 2010 she had joined the research team as senior researcher at the Centre for research and development, Institute for Social Research in Zagreb. Her main areas of research were work values, career development, organizational stress, motivation to learn, learning strategies, management in higher education, teacher education and teacher professional development. Besides academic career she was committed to the transfer of her scholarship into educational policy projects as well as into pre- tertiary educational settings. She had management experience in higher education as head of the Psychology department and vicedean for student at Faculty of philosophy, vice-rector for international relations of the University of Zagreb, Head of the Accreditation board of Agency for science and higher education, and Head of the Center for educational research and development at Institute for Social Research in Zagreb.

VlatKa Domović, $\mathrm{PhD}$, is a full professor at the Faculty of Teacher Education, University of Zagreb. Her research interests include: teacher education and training, educational administration, comparative education, and school effectiveness. Besides academic career she is committed to the transfer of her scholarship into educational policy projects and she has been involved in development of programs for in - service teacher training especially in the field of curriculum development and school improvement. 